\title{
Contributions
}

Christina Felfe* and Larissa Zierow

\section{After-School Center-Based Care and Children's Development}

\begin{abstract}
What is the impact of after-school center-based care on the development of primary school-aged children? Answering this question is challenging due to non-random selection of children into after-school center-based care. We tackle this challenge using detailed data of the German Child Panel and employing a value-added method. While we do not find significant effects on average, our analysis provides evidence for beneficial returns to after-school center-based care attendance for more disadvantaged children. To be more precise, children of less educated mothers and low-income families benefit from attending after-school care centers in terms of their socio-behavioral development.
\end{abstract}

Keywords: child care, child development, value-added estimation JEL Classifications: J13, I21

\section{Introduction}

Labor market participation of women with school-aged children is nowadays common practice in most mature economies: $76 \%$ of all US-American mothers with school-aged children between 6 and 18 years old are employed (Bureau of Labor Statistics 2011); in the European Union, the employment rate of mothers with primary school-aged children between 6 and 10 years old amounts to $70 \%$

\footnotetext{
*Corresponding author: Christina Felfe, University of St. Gallen and CESifo, Varnbüelstrasse 14, St Gallen CH-9000, Switzerland, E-mail: christina.felfe@unisg.ch Larissa Zierow, Ludwig-Maximilians-University, Munich, Germany, E-mail: larissa.zierow@econ.Imu.de
} 
and in Germany to 75\% (Eurostat 2011). While the overall employment rate is similar, the full-time employment rate varies greatly across these regions: In the US, $58 \%$ of mothers are having a full-time job, whereas $43 \%$ do so in the European Union. In Germany, only $23 \%$ of mothers are employed at a full-time basis. One reason often stated for not taking up a full-time job is the difficulty to coordinate work with the care facilities available for children once the school day ends (Heimer, Henkel, and Donges 2011). ${ }^{1}$

As a result, the main care provider for primary school-aged children is still the mother. In Germany, for instance, $64 \%$ of all primary school-aged children are looked after by their mothers. ${ }^{2}$ Alternative care providers are relatives (26\%), friends (7\%) and nannies (7\%). In addition to these informal arrangements, $26 \%$ of all primary school-aged children are attending after-school care centers. ${ }^{3}$ These centers are provided by municipalities and non-profit organizations and allow mothers to participate in the labor market while their children are taken care of in a regulated setting. Yet, do children benefit or rather suffer from attending such centers in terms of their school performance and socio-behavioral development?

The answer to this question depends crucially on the quality of the child care center as well as the quality of the alternative care modes. In after-school care centers, most staff holds a pedagogical degree and supervises the children through the afternoon hours. Groups, however, are rather large with 17-23 children per group with 1-2 pedagogues. As described above, the main alternative care mode is the mother or another family member. As a consequence, the quality of the care provided might be very heterogeneous and might vary depending on the family background. For instance, a child from an advantaged family background might receive high attention and learning support as well as attend high-quality leisure activities. In contrast, less educated or less advantaged mothers might possess little knowledge about development-enhancing activities and a lower capacity to help with children's homework. Thus, the impact of center-based care attendance might vary substantially across children from different family backgrounds and is ultimately an empirical question.

1 Table 6 in the Appendix provides information about the length of a school day for several European countries and the US. Comparing the length of the typical primary school day between Germany and European countries as well as the US reveals that school days are relatively short in Germany.

2 Own calculations based on the German Socio-Economic Panel, 2011.

3 These numbers do not add up to $100 \%$ as families often rely on combinations of the alternative care modes. 
The present paper provides novel empirical evidence about the relationship between children's development and after-school center-based care. Our analysis is based on data of the German Child Panel (GCP) which contains information on children's school grades and measures of children's socio-behavioral development, center-based after-school care attendance, and individual background characteristics of primary school-aged children between 2002 and 2005 . Our estimation targets first the mean effect of center-based after-school care on children's school performance and socio-behavioral development. Yet, to do justice to the heterogeneity in counterfactual care modes, we distinguish between different family backgrounds. In particular, we stratify with respect to maternal education and household income.

The main challenge our empirical analysis faces is non-random selection into care. First of all, the major reason for sending a child to center-based care is mothers' labor force participation. ${ }^{4}$ There are several features that might characterize working mothers that simultaneously influence their child caring activities and thus, their children's development. For instance, higher educated or more motivated women are more likely to work. One further reason for participation in after-school center-based care might be a child's school performance. In other words, we might face reverse causality. Given such non-random selection into care, a simple mean comparison might reveal diverging performance between children attending after-school care centers and children not attending after-school care centers, while this is not necessarily the result of center-based care attendance.

To deal with these issues, we exploit the longitudinal nature of our data and employ a value-added approach. In other words, we regress a child's development measures in the current period on after-school care attendance in the previous period as well as on a set of lagged development measures. This approach has the following advantages. First, it splits consecutive periods and analyzes the impact of after-school center-based care attendance in the previous period on a child's development in the current period. By default the dependent variable - alternative indicators for a child's development - cannot influence the after-school care arrangements in the previous period. Second, it controls for a set of lagged outcome measures accounting for the fact that after-school center-based care attendance might be due to a child's prior performance which in turn is a strong predictor for a child's current performance. In addition, lagged outcome measures are well-suited proxies for prior inputs, both observed and unobserved ones, into children's development function. As a result, any

4 Eighty percent of the mothers in our data state their labor force participation as the main reason for enrolling their children into after-school center-based care. 
variables influencing children's after-school center-based care attendance and children's development up to this point should be captured by the lagged outcome measures. Yet, in case there are any further unobserved determinants of children's after-school center-based care attendance and children's current development that are captured neither by the set of lagged outcome measures nor by the included control variables - e.g. future employment plans of the mother or marital instability - the estimates of the value-added approach might still be prone to omitted variable bias. ${ }^{5}$

Our analysis does not reveal any significant effects of participation in afterschool center-based care on children's development on average. Estimates based on subgroup analysis, however, point toward significant benefits from afterschool center-based care attendance for more disadvantaged children. In particular, children of less educated mothers and of low-income families benefit from attending after-school center-based care in terms of their socio-behavioral development.

Existing research on after-school programs has focused mainly on special programs targeted at disadvantaged children in the US. Heavily evaluated programs are the "Extended Services School Initiative" - a comprehensive after-school program at 60 US-American schools targeted at high-need children in 1st to 8th grade - or "LA's Best" - an "After-School Education and Enrichment Program” established in 1988 in LA's poorest elementary schools. Regarding the first program, Grossman et al. (2002) establish beneficial effects of the program in terms of decreased risk-taking behavior, improved school attitudes and grades, extended social networks and higher self-confidence. Brooks, Mojica, and Land (1995) analyze the "LA's Best" program during its initial phase and find that the program helped the participating children to catch up with non-attending children in terms of academic development. Huang et al. (2000) evaluate the intermediate and longer run effects of the program. Conditional on gender, ethnicity, English proficiency and family income, they find positive effects on children's propensity to perform well in standardized tests and children's attitudes toward school. A further study by Huang et al. (2008) distinguishes with respect to the intensity of program exposure (i.e. days of attendance during a school year) and finds positive correlations between exposure and students' math achievements.

Evaluations of targeted programs suggest that after-school center-based care has a positive impact on child development. Yet, based on their findings, one can hardly infer anything about the effects of universal after-school care

5 For a discussion on the likelihood and direction of such a bias please refer to Section 4 . 
programs. In targeted programs, the participating children come from rather disadvantaged family backgrounds and enjoy high-quality programs directly aligned with their needs. Thus, the effects of those programs are likely to present an upper bound of potential effects of universal after-school care (Blau and Currie 2006).

To the best of our knowledge, the only study that estimates the effect of nontargeted after-school supervision on child outcomes is the one by Aizer (2004). Her paper, however, focuses on the consequences of unspecified adult supervision for the behavioral development of children aged 10-14 years. The chosen empirical strategy - family fixed effects - allows Aizer to account for nonrandom selection of mothers into the work force and thus non-random selection into differential arrangements of after-school care. She finds that children with adult supervision are less likely to skip school, use alcohol or marijuana, steal or hurt someone.

Our study contributes to the literature in at least four ways: First, to the best of our knowledge, we are the first to evaluate the impact of universal afterschool center-based care. As pointed out above, the existing literature focuses only on targeted child care programs or on unspecified adult supervision. ${ }^{6}$ Second, our study focuses on both school performance and socio-behavioral development and thus provides a broad picture of the effects of after-school care provision on several development dimensions important for later success in life. Third, we exploit individual panel data and employ a value-added method to address the problem of endogenous selection into after-school care. Forth, we stratify our sample along several important determinants of child development. Doing so is crucial as it reveals which children benefit and which children lose from attending after-school care centers. Finally, in contrast to the existing literature which focuses exclusively on the US, we focus on a European country, namely Germany.

The remainder of this study is structured as follows. Section 2 provides some basic information on after-school center-based care in Germany. Section 3 introduces the dataset and provides descriptive statistics. Section 4 explains the empirical strategies, while Section 5 presents the results of the estimations. Section 6 concludes.

6 There exist several evaluations of universal center-based care for pre-school children (Baker, Gruber, and Milligan 2008; Cascio 2009, and Fitzpatrick 2008 for North-America; Dustmann, Raute, and Schönberg 2012; Felfe, Nollenberger, and Rodriguez-Planas 2013 and Havnes and Mogstad 2011 for several European countries). Yet, to the best of our knowledge, there is no study analyzing the impact of universal care for primary school-aged children. 


\section{Institutional background}

After-school center-based care in Germany exists in four different forms: Afterschool care clubs, the so-called "Hort", are the most common mode of a formal care setting for primary school-aged children. Children go there as soon as school is over, have lunch, do their homework, can play, and so on. The other three concepts are lunchtime supervision, afternoon supervision and homework supervision. These types of care are often taking place in the hort or in other child care institutions under public responsibility (Riedel et al. 2005). All of the four types have in common that guided supervision is provided to children after school.

Overall, there are about 455,000 slots in after-school center-based care available to school-aged children in 2002 (the year our dataset, the GCP, originates from; please refer to Section 3 for details on the data). Given the total number of children aged 6-10 years at this time (about 3.3 million), this means that on average every seventh child has access to center-based care. Most of these formal care slots are allocated in East Germany, where 67.7\% of schoolaged children are offered formal care in the afternoon. Their West German peers (excluding those living in a city state) face a much smaller supply: only $6 \%$ of them have the chance to get a place in after-school center-based care. This difference is striking and questions a joint analysis of East and West Germany. Given the rather small sample available for East Germany, our analysis focuses therefore on children in West Germany only.

Figure 1 and Table 1 illustrate the supply of after-school care centers in the different West German states and counties. Most states exhibit offer rates lower than 10\%. Exceptions are the city states, Berlin, Bremen and Hamburg, where 1 out of 5, 1 out of 4, and even 1 out of 2 children have access to after-school care, respectively. Yet, there is substantial variation within states: in Bavaria, for instance, the minimum offer rate just exceeds zero $(0.1 \%)$, while the maximum offer rate amounts to $32.5 \%$. Such differences are mostly driven by city-countryside differences. For instance, in Munich in 2002, 1 out of 3 children has access to a slot in after-school care, while in Oberallgäu, a rather rural Bavarian county, only 1 out of 60 children has access to a slot in after-school care.

Is this low supply of after-school care met by an equally low demand for child care facilities? Employment rates of mothers living in West Germany with children aged 6-10 lie above European average (2002: 65.7\%). However, what is more important for defining a potential demand for after-school center-based care is whether these mothers work full-time or part-time. In fact, as is shown in Table 2 only $16.4 \%$ of mothers in West Germany work full-time. Thus, at least $10.4 \%$ of all West German primary school-aged children have a mother who 


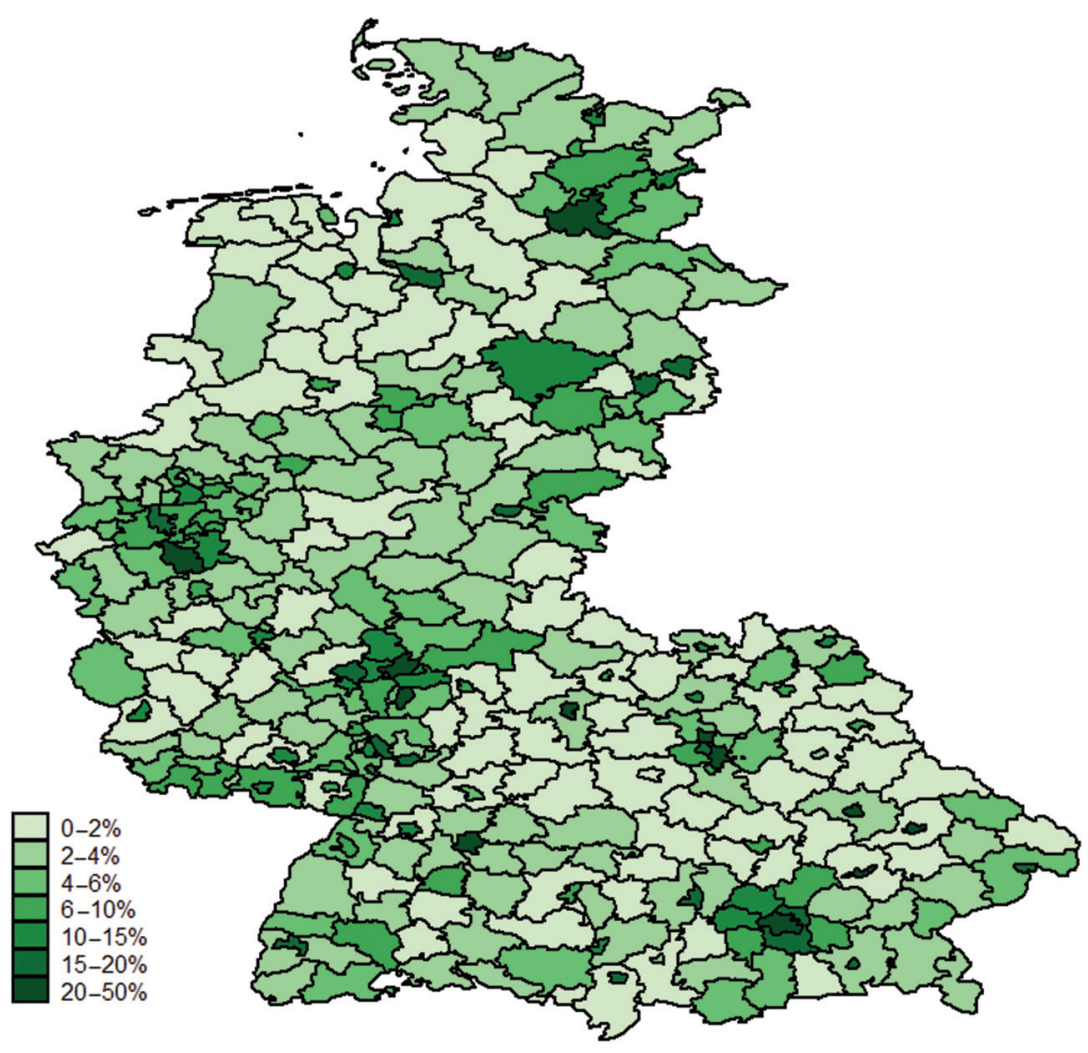

Figure 1: Regional variation of after-school center-based care supply in West Germany Note: County-specific offer rate, i.e. after-school care slots as percentage of primary schoolaged children.

Source: Figure based on data from Riedel et al. 2005).

works full-time, but do not have access to a slot in center-based care $(16.4 \%$ of full-time working mothers vs an after-school center-based care offer rate of only $6.0 \%)$. In other words, we face most likely a situation of insufficient supply. ${ }^{7}$ In

7 Further evidence for a gap between supply and demand of after-school care slots is the existence of priority setting rules after-school care centers have to adhere to when considering applications. They usually have to prioritize (1) children living in the same district, (2) children living with single mothers, (3) children with two fulltime-working parents, (4) children whose siblings are already enrolled in the center, (5) children with disabilities and (6) children in families in distress (e.g. financial problems). Notice that the priority criteria differ slightly depending on state and county. 
Table 1: Regional variation in after-school center-based care supply, West Germany 2002

\begin{tabular}{|c|c|c|c|}
\hline & \multirow{2}{*}{$\begin{array}{r}\text { Offer rate in \% } \\
\begin{array}{r}\text { Average all } \\
\text { counties }\end{array}\end{array}$} & \multirow{2}{*}{$\begin{array}{r}\text { Offer rate in \% } \\
\begin{array}{r}\text { County with } \\
\text { lowest supply }\end{array}\end{array}$} & \multirow{2}{*}{$\begin{array}{r}\text { Offer rate in \% } \\
\text { County with } \\
\text { highest supply }\end{array}$} \\
\hline & & & \\
\hline Baden-Wurttemberg & 4.8 & 0.6 & 20.5 \\
\hline Bavaria & 7.1 & 0.1 & 32.5 \\
\hline Berlin (City State) & 59.2 & - & - \\
\hline Bremen (City State) & 18.3 & 11.6 & 19.9 \\
\hline Hamburg (City State) & 24.9 & - & - \\
\hline Hesse & 9.9 & 0.9 & 40.2 \\
\hline Lower Saxony & 4.5 & 0 & 16.8 \\
\hline North-Rhine Westphalia & 5.6 & 0.8 & 20.1 \\
\hline Rhineland-Palatinate & 4.7 & 0.5 & 14.7 \\
\hline Saarland & 6.5 & 3.8 & 9.2 \\
\hline Schleswig-Holstein & 5.5 & 0.5 & 14.5 \\
\hline West Germany (without City States) & 6.0 & - & - \\
\hline City States & 34.1 & - & - \\
\hline
\end{tabular}

Source: Riedel et al. (2005, Tables 20 and 44).

Table 2: Employed mothers with children aged 6-10 in 2002

\begin{tabular}{lrr}
\hline & West Germany & East Germany \\
\hline \% Employed of all mothers & 65.7 & 69.7 \\
\% Full-time employed mothers & 16.4 & 42.3 \\
\% Part-time employed mothers & 49.3 & 26.4 \\
\hline
\end{tabular}

Source: Genesis-Online.

response to this excess demand, public efforts are steadily rising to expand the amount of available facilities. ${ }^{8}$

What characterizes after-school center-based care in Germany? After-school care centers are not only a place where to keep children safe while parents are at work, but society has certain expectations about what these centers should offer. Federal law from 1990/1991 states that care centers have to promote children's development and help children to become responsible and active members of

8 Table 7 in the Appendix shows that supply increased from 1998 onward in all West German states, with exception of Northrhine-Westfalia, where the concept of all-day-schools was established instead. 
the society (§ 22 SGB VIII (1)). In after-school center-based care, children receive support with their homework, get lunch, do different kinds of supervised activities or simply play with their peers. The quality of supervision is relatively high. As Table 3 shows, on average more than two thirds of the staff hold a degree in child care, a non-university formation over 3 years after high school. About $6-8 \%$ of the staff even holds a university diploma in social pedagogy. Yet, in some states, there is also a substantial part of staff having only completed a short-term formation in child care (less than 3 years), the West German average lies at $10 \%$. Other measures to judge the quality of child care institutions are group size and children-per-staff ratio. The average group size in West Germany varies between 17 and 23 children per group and thus is comparable to or only slightly below the class size in primary school. The average children-per-staff ratio, however, ranges between 9 and 12 .

Table 3: Regional variation of after-school center-based care quality in West Germany

\begin{tabular}{|c|c|c|c|c|c|}
\hline \multirow[t]{2}{*}{ State } & \multirow[t]{2}{*}{$\begin{array}{r}\text { Group } \\
\text { size }\end{array}$} & \multirow[t]{2}{*}{$\begin{array}{l}\text { Children- } \\
\text { per-staff }\end{array}$} & $\begin{array}{l}\text { Pedagogical } \\
\text { Background }\end{array}$ & $\begin{array}{l}\text { Pedagogical } \\
\text { Background }\end{array}$ & $\begin{array}{l}\text { Pedagogical } \\
\text { Background }\end{array}$ \\
\hline & & & $\begin{array}{r}\text { University } \\
\text { degree } \\
\text { in \% of staff }\end{array}$ & $\begin{array}{r}\text { Non-university } \\
\text { formation over } \\
3 \text { years } \\
\text { in \% of staff }\end{array}$ & $\begin{array}{r}\text { Short-term } \\
\text { formation } \\
\text { in \% of staff }\end{array}$ \\
\hline Baden-Wurttemberg & 22 & 10 & 8.1 & 61.2 & 3.4 \\
\hline Bavaria & 23 & 10 & 3.7 & 57.1 & 25.8 \\
\hline Berlin (C) & - & - & 2.5 & 85.4 & - \\
\hline Bremen (C) & 20 & 11 & 17.4 & 65.8 & 3.3 \\
\hline Hamburg (C) & 20 & 12 & 4.0 & 64.7 & 3.2 \\
\hline Hesse & 17 & 10 & 12.6 & 65.3 & 3.5 \\
\hline Lower Saxony & 19 & 10 & 8.4 & 70.8 & 14.9 \\
\hline $\begin{array}{l}\text { North-Rhine } \\
\text { Westphalia }\end{array}$ & 20 & 9 & 2.7 & 85.3 & 3.9 \\
\hline Rhineland-Palatinate & 17 & 9 & 7.2 & 73.7 & 6.7 \\
\hline Saarland & 20 & 10 & 2.3 & 83.7 & 5.9 \\
\hline Schleswig-Holstein & 17 & 10 & 4.6 & 70.0 & 18.3 \\
\hline $\begin{array}{l}\text { West Germany } \\
\text { (without C) }\end{array}$ & 19 & 10 & 6.2 & 70.9 & 10.3 \\
\hline City states & 20 & 12 & 8.0 & 72.0 & 3.3 \\
\hline
\end{tabular}

Source: Federal Statistical Office - Kinder- und Jugendhilfestatistik.

These numbers make evident that the environment of after-school center-based care is probably very different from most of the potential counterfactual situations children face when not attending center-based care. First, the time in 
center-based care is characterized by being in a rather large group of children. This could be beneficial for children's socio-behavioral development due to peer interactions that do not necessarily take place when being at home. Yet, it could also be that the large group of children has negative consequences for a child due to a higher stress level and negative spill-over effects, in particular if children with learning or conduct difficulties are attending after-school care centers. Second, in after-school care centers there is at least one adult present who has a pedagogical background and offers educational guidance through the afternoon hours. This implies that a child attending center-based care has the opportunity to discuss her homework with a qualified pedagogue which might help the child improving in school. Given the high children-per-staff ratio and the short formation period of some staff it is, however, questionable if the time and help that can be allotted to each child is enough to "make a difference”.

Care provided by mothers or family members can be very heterogenous and depends on the family background. For instance, better educated mothers may be able to provide their children with learning support as well as with development-enhancing activities - such as reading to the child, undertaking cultural activities, enrolling their children in high-quality leisure activities. Less educated mothers may not be able to provide their children with care of a comparable quality, either because they lack the ability, information or financial resources. Another dimension which might be crucial for determining inputs into children's human capital production function is the household income as it puts restrictions on which kind of activities a child can attend in the afternoon hours. $^{9}$

Taken together, there might be striking differences in counterfactual care modes. As a result the impact of attendance to after-school centers on children's development may differ substantially across children from different family backgrounds. Our analysis therefore stratifies with respect to the abovementioned two dimensions: mothers' education and household income. These dimensions might serve as a good proxy for the quality of maternal or family care.

9 In addition, the fact whether a child lives in a single-parent household or a two-parent household might be potentially crucial for the quality of care a child receives at home. Single mothers may simply lack the time to provide their children with high-quality care. Unfortunately, sample size issues (47 single mothers in our sample) prevent us from any meaningful analysis of the subsample of children who live in a single-parent household. 


\section{Data}

\subsection{Data}

Our analysis is based on data from the GCP. The GCP is a longitudinal survey conducted by the German Youth Institute from 2002 to 2005. Besides providing access to a wide range of information on important background characteristics, the GCP contains a broad spectrum of indicators on child development and child care provision. The survey is based on two cohorts, children born between 10/1993 and 09/1994 who were 8 years old when being interviewed for the first time, and children born between 10/1996 and 09/1997 who were 5 years old at the time of the first interview. The children and their parents were interviewed in three stages at intervals of approximately 1.5 years: 2002, 2004 and 2005. ${ }^{10}$

Our analysis considers interviews within the time span when children attended primary school. Therefore, we draw on the first and second interview with mothers of the older cohort, i.e. when children were between 8 and 10 years old. Following the same logic, we use the second and third interview with mothers of the younger cohort, i.e. when children were between 7 and 9 years old. Henceforth, we refer to these two interviews as the respective first and second period. We construct the sample as follows: First, we exclude all observations from children living in East Germany for reasons explained in Section 2. We also discard all observations in the city states Berlin and Bremen because of differences in the definition of after-school center-based care. ${ }^{11}$ We do not keep children who are implausibly old or young in our sample. ${ }^{12}$ Moreover, we drop all cases where information on outcomes or treatment is missing. Finally, we restrict our sample to children who were present in both, the respective first and

10 At each stage, all mothers were interviewed and all fathers were asked to complete a questionnaire. Unfortunately, participation of fathers was very low and thus, their answers will not be considered in this paper.

11 The reason for doing so is that the distinction between all-day school and after-school center-based care is not clear cut in those two states (after-school care often takes place inside the school building). As such, mothers' answers to the question whether their children attend after-school center-based care might not be comparable between families living in Berlin and Bremen and the remaining states.

12 In other words, we do not consider children who deviate 2 or more years from the originally targeted age group. 
second period. This leaves us with 857 children, 363 of the younger cohort and 494 of the older cohort. ${ }^{13}$

We create the treatment variable "afterschool" that indicates whether the child attends after-school center-based care. This variable takes the value 1 if a child uses at least one of the following after-school center-based care settings: hort, homework supervision, lunchtime supervision and/or afternoon supervision.

The GCP survey contains questions covering a broad spectrum of child development dimensions, inspired in particular by the Child Behavior Checklist CBCL (Aschenbach and Edelbrock 1981) and the Temperament Survey by Windle and Lerner (1986) and Wahl (2008). We group the numerous (14) questions according to the logic of the Strengths and Difficulties Questionnaire (SDQ), a brief behavioral screening questionnaire widely used in youth psychology research. This makes our development indicators more comparable to a recently emerging literature on the impact of early child care on children's non-cognitive development (see for instance Datta-Gupta and Simonsen 2010). The SDQ score is built on the following four development dimensions $^{14}$ :

- Emotions: information on how often a child is happy, nervous, worried, easily scared, and so on.

- Conduct: information on how often a child has temper tantrums, fights with other children or bullies them, and so on.

- Hyperactivity: information on whether a child gets easily distracted, acts before thinking, cannot stay still for long, and so on.

- Peer relations: information on whether a child is generally liked by other children, is rather solitary, is bullied by other children, and so on.

13 Table 8 in the Appendix provides an overview of our sample construction. Notice that there are significant differences between the original dataset and the sample used in this study regarding (1) the household income, i.e. children dropped from the sample live more often in a household with a net income below 2,250 euros per month (12\% difference), (2) the immigrant background, i.e. children dropped from the sample have more often an immigrant background (6\% difference), (3) the education of the mother, i.e. children dropped from the sample have more often a less educated mother (5\% difference) and (4) the birth weight of the child, i.e. children dropped from the sample had more often a low birth weight ( $4 \%$ difference). As a result, the remaining sample might not be representative anymore. Nevertheless, if our hypothesis is true and after-school care should be especially beneficial for children with a less advantaged background, the arising selection leads to estimates that present a lower bound of the effect of after-school center-based care attendance.

14 Table 9 in the Appendix shows the survey questions concerning children's development and how we group them into the different developmental categories. 
Following the practice of the SDQ we construct an average score based on the four development dimensions - emotions, conduct, hyperactivity and peer relations - and thus, obtain a measure for children's socio-behavioral development. In addition, we average a child's performance in the core subjects mathematics, reading and writing, which serves as our overall measure of school performance. We standardize all development indicators to have a zero mean and a standard deviation of one. Interpretation of the indicators is straightforward: the higher the value of an indicator the less difficulties a child has in the respective development dimension, i.e. the better is her performance in the respective dimension.

One potential disadvantage of the GCP dataset is that all developmental indicators are derived from a mother's judgment of her child's abilities and characteristics. A problem could arise if mothers sending their child to after-school care centers justify their absence and thus overestimate their children's development. Yet, such reporting problems may be primarily present for more subjectively measured outcomes, such as personality traits, and less for more objectively assessed outcomes, such as school performance. Thus, if there are only differences observable with respect to subjectively measured outcomes, but not with respect to more objectively reported outcomes, misreporting may be an issue.

A further problem might arise if maternal judgment capacity changes when children access after-school care. In other words, some developmental dimensions (like fighting with other children) may only become apparent once the child enters formal care and spends time with a larger peer group. Yet, basically all children have attended Kindergarten from age 3 onward and thus have been exposed for a longer time to institutionalized care. Moreover, children are already enrolled in school. Thus, at this point in time parents should have already had the opportunity to observe their child both in the family and in the outside-family context.

Finally, one further disadvantage of the GCP data is that children's school performance is not measured by standardized tests. The indices are based on recent school grades (which are the result of non-standardized assessments of written and oral performance in the class room). The school performance measure may thus be biased by different grading policies across the German states. Taking this into account, we control for state fixed effects in our regressions. Doing so helps us furthermore to tackle any differences in the school infrastructure and curricula as well as in the public funding for day care institutions at the state level (notice that the educational system is under the jurisdiction of the states).

Besides public care settings, there are other important determinants of children's development. The most relevant ones are a family's socio-economic 
status, parental education and a child's initial endowments (Blau 1999; Case, Lubotsky, and Paxson 2002; Currie 2009; Almond and Currie 2011; Black, Devereux, and Salvanes 2005). Our set of control variables includes therefore gender, immigrant background, birth weight, prevalence of any kind of health disorder, pre-school attendance, mother's age, single parenthood, education of the mother and finally household net income and number of siblings. To do justice to the literature which puts forward the socio-economic environment as a further determinant of child development (among others Kling, Liebman, and Katz 2007), we additionally consider a set of regional characteristics measured at the county level (population density, unemployment rate, female employment rate, net migration, GDP per capita and primary school-aged children as percentage of the total population). ${ }^{15}$ In addition, we distinguish between rather urban and rather rural counties within each state by including a dummy indicating whether the county of residence is rather urban as well as the interactions between this dummy and the set of state dummies.

\subsection{Descriptives}

This section provides first evidence on the raw differences between Treated children - those who attend after-school center-based care in the first wave and Control children - those who do not attend after-school center-based care in the first wave. Since the available data do not allow us to derive precise statements about the afternoon activities of control children compared to treated children, we need to be very general when describing the difference between the two groups: Children in the treatment group receive schooling in the morning and after-school center-based care in the afternoon. Children in the control group receive schooling in the morning and anything else than after-school center-based care in the afternoon. ${ }^{16}$

Table 4, Panel A displays descriptive statistics on children's development. The first column displays the means of the overall sample, columns 2 and 3 display the mean values of the treated and the control group, respectively, and column 4 displays the difference between the two groups along with the

15 The regional data are from the INKAR database provided by The Federal Institute for Research on Building, Urban Affairs and Spatial Development and merged with the GCP data via county codes.

16 Table 10 in the Appendix hints at differences regarding afternoon activities: treated children are by 8 percentage points less likely to receive private music lessons or sport training than control children. Moreover, treated children are by 9 percentage points less likely to have lunch together with their family than control children. 
Table 4: Descriptive statistics according to after-school care usage

\begin{tabular}{|c|c|c|c|c|c|}
\hline & \multirow{2}{*}{$\begin{array}{c}\text { Pooled } \\
N=857\end{array}$} & \multirow{2}{*}{$\begin{array}{r}\text { No } \\
\text { afterschool } \\
N=689\end{array}$} & \multirow{2}{*}{$\begin{array}{r}\text { Afterschool } \\
N=168\end{array}$} & \multicolumn{2}{|c|}{$\begin{array}{r}\text { Afterschool vs no } \\
\text { afterschool }\end{array}$} \\
\hline & & & & Diff. & $\begin{array}{l}\text { Std. } \\
\text { error }\end{array}$ \\
\hline \multicolumn{6}{|l|}{ Panel A. Child outcomes } \\
\hline \multicolumn{6}{|l|}{ School performance } \\
\hline Grades & 0.093 & 0.127 & -0.045 & $-0.172^{\star \star}$ & $(0.086)$ \\
\hline \multicolumn{6}{|l|}{ Socio-behavioral development } \\
\hline SDQ score & -0.040 & 0.022 & -0.292 & $-0.314^{\star \star \star}$ & $(0.086)$ \\
\hline \multicolumn{6}{|l|}{ Panel B. Child characteristics } \\
\hline Age & 7.852 & 7.862 & 7.810 & -0.053 & $(0.056)$ \\
\hline Low birth weight & 0.113 & 0.107 & 0.137 & 0.030 & $(0.027)$ \\
\hline Disorder & 0.183 & 0.174 & 0.220 & 0.046 & $(0.033)$ \\
\hline Female & 0.494 & 0.501 & 0.464 & -0.036 & $(0.043)$ \\
\hline German & 0.914 & 0.923 & 0.875 & $-0.048^{\star \star}$ & $(0.024)$ \\
\hline Early care attendance & 0.177 & 0.163 & 0.238 & $0.076^{\star \star}$ & $(0.033)$ \\
\hline \multicolumn{6}{|l|}{ Panel C. Family characteristics } \\
\hline Mother's education: primary & 0.20 & 0.21 & 0.16 & -0.054 & $(0.035)$ \\
\hline Mother's education: secondary & 0.59 & 0.60 & 0.52 & $-0.079^{\star}$ & $(0.042)$ \\
\hline Mother's education: university & 0.19 & 0.16 & 0.29 & $0.125^{\star \star \star}$ & $(0.033)$ \\
\hline Mother is working & 0.63 & 0.60 & 0.77 & $0.173^{\star \star \star}$ & $(0.041)$ \\
\hline Mother is single & 0.05 & 0.03 & 0.14 & $0.109^{\star \star \star}$ & $(0.019)$ \\
\hline Age of mother: under 30 & 0.06 & 0.06 & 0.05 & -0.015 & $(0.020)$ \\
\hline Age of mother: $30-34$ & 0.17 & 0.17 & 0.18 & 0.010 & $(0.032)$ \\
\hline Age of mother: $35-39$ & 0.40 & 0.41 & 0.39 & -0.015 & $(0.042)$ \\
\hline Age of mother: $40-44$ & 0.29 & 0.28 & 0.30 & 0.021 & $(0.039)$ \\
\hline Age of mother: $45-49$ & 0.07 & 0.07 & 0.06 & -0.013 & $(0.022)$ \\
\hline Age of mother: 50 plus & 0.01 & 0.01 & 0.01 & 0.006 & $(0.007)$ \\
\hline Child has siblings & 0.83 & 0.85 & 0.77 & $-0.083^{* * \star}$ & $(0.032)$ \\
\hline Number of persons in the household & 4.23 & 4.29 & 3.97 & $-0.319 * \star \star$ & $(0.097)$ \\
\hline $\begin{array}{l}\text { Total net income } 0-1,250 \\
\text { euro/month }\end{array}$ & 0.05 & 0.05 & 0.06 & 0.012 & $(0.019)$ \\
\hline $\begin{array}{l}\text { Total net income } 1,250-2,250 \\
\text { euro/month }\end{array}$ & 0.28 & 0.27 & 0.33 & $0.065^{\star}$ & $(0.039)$ \\
\hline $\begin{array}{l}\text { Total net income } 2,250-3,250 \\
\text { euro/month }\end{array}$ & 0.35 & 0.36 & 0.27 & $-0.091^{\star \star}$ & $(0.041)$ \\
\hline $\begin{array}{l}\text { Total net income higher than } 3,250 \\
\text { euro/month }\end{array}$ & 0.25 & 0.25 & 0.26 & 0.011 & $(0.038)$ \\
\hline
\end{tabular}


Table 4: (Continued)

\begin{tabular}{|c|c|c|c|c|c|}
\hline & \multirow{2}{*}{$\begin{array}{l}\text { Pooled } \\
\mathbf{N}=\mathbf{8 5 7}\end{array}$} & \multirow{2}{*}{$\begin{array}{r}\text { No } \\
\text { afterschool } \\
N=689\end{array}$} & \multirow{2}{*}{$\begin{array}{r}\text { Afterschool } \\
N=168\end{array}$} & \multicolumn{2}{|c|}{$\begin{array}{r}\text { Afterschool vs no } \\
\text { afterschool }\end{array}$} \\
\hline & & & & Diff. & $\begin{array}{l}\text { Std. } \\
\text { error }\end{array}$ \\
\hline \multicolumn{6}{|l|}{ Panel D. Regional characteristics } \\
\hline Urban county & 0.26 & 0.23 & 0.37 & $0.141^{\star \star \star}$ & $(0.038)$ \\
\hline Population density & 328 & 289 & 490 & $201^{\star \star \star}$ & $(59.24)$ \\
\hline Unemployment rate & 8.84 & 8.73 & 9.30 & $0.568^{\star \star \star}$ & $(0.219)$ \\
\hline Female employment rate & 7.98 & 7.92 & 8.25 & $0.327^{\star}$ & $(0.172)$ \\
\hline Net migration & 3.29 & 3.28 & 3.32 & 0.045 & $(0.267)$ \\
\hline After-school care slots per child & 0.07 & 0.07 & 0.11 & $0.039^{\star \star \star}$ & $(0.006)$ \\
\hline GDP p.c. in 1,000 euro & 28.65 & 27.90 & 31.72 & $3.821^{\star \star \star}$ & $(0.985)$ \\
\hline$\%$ of children aged $6-10$ & 4.23 & 4.27 & 4.06 & $-0.210^{\star \star \star}$ & $(0.044)$ \\
\hline
\end{tabular}

Note: The statistics are based on the first period of the GCP survey. Treated children are those children who attended after-school center-based care in the first period. Control children are those children who did not. Standard errors are in parentheses. ${ }^{*} p<0.10$, ${ }^{\star \star} p<0.05,{ }^{\star \star *} p<0.01$.

respective standard error. Treated children perform on average significantly worse in school (0.17 standard deviation, henceforth sd). Treated children also display a significantly worse performance in the non-cognitive dimension "SDQ score" $(0.31 \mathrm{sd})$. Table 11 in the Appendix shows the differences between treated and control children regarding the four components of the SDQ score. Treated children perform significantly worse regarding their emotional stability $(0.18 \mathrm{sd})$, conduct $(0.20 \mathrm{sd})$ and hyperactivity $(0.28 \mathrm{sd})$. The difference between treated and control children's peer relations is not significant.

Table 4, Panel B contains information on several child characteristics. It shows that treated and control children do not differ significantly with respect to age, birth weight, health disorder and gender. Yet, foreign children and children who were already enrolled in formal care under the age of 3 years are more likely to be enrolled in an after-school care center (by 5 and 7.6 percentage points, respectively). Do treated and control children differ with respect to their family background? Table 4, Panel $\mathrm{C}$ shows that - as already highlighted before - mothers' labor force participation appears to be one of the main correlates with children's participation in after-school center-based care. We observe a significant difference in the labor force participation of mothers whose children attend and do not attend after-school care (77\% vs 60\%). Among those mothers who are working the ones who use after-school care for their child have significantly more often a fulltime-job (23\% vs $13 \%$, see Table 12 in the 
Appendix). ${ }^{17}$ Major differences are also observed with respect to mothers' education: Mothers of treated children are less likely to possess only a primary or secondary school degree (by 5.4 percentage points and 7.9 percentage points, respectively), but more likely to have attended university (by 12.5 percentage points). There is, moreover, a large difference regarding single parenthood: $14 \%$ of mothers belonging to the treated group are single mothers. This percentage is much smaller for the control group (3\%). Moreover, treated children have less often siblings than control children ( $77 \%$ vs $85 \%$ ), and thus also a lower number of persons living in the same household (4.3 vs 4 persons on average). We also observe that families with a higher net income per month are less likely to send their child to an after-school care center: $32 \%$ of control children live in a family with a household income below 2,250 euros per month, while 39\% of treated children do so. In contrast, $61 \%$ of control children live in a family with a household income above 2,250 euros per month, while only 53\% of treated children do so. Regarding the regions of residence, children in formal care live more often in regions with a higher population density, a higher unemployment rate, a higher GDP per capita, a lower percentage of primary school-aged children and a higher supply of after-school care slots per child. Finally, afterschool care attendance is generally higher in urban areas (38\% vs $23 \%$ ). As such, in our analysis, we not only control for a set of state dummies but also distinguish within states between more and less urban counties.

Overall, the above findings indicate that children attending after-school center-based care - compared to children who are not attending - stem from a more advantaged background in terms of mother's education. However, treated children have also fewer siblings and reside more often in a single-parent household, both factors that may imply that treated children are less likely to encounter social interactions at home. Moreover the parental income of treated children is lower which might influence the family's capacity to arrange development stimulating activities for their child. Thus, based on the descriptive evidence, it is not obvious whether the selection into after-school care would lead to over- or understating the impact of after-school care attendance when just comparing the raw differences between control and treated children as shown in Table 4, Panel A.

To understand a bit better whether families of treated children provide on average an adverse environment for a child's development, Table 13 in the Appendix compares both groups with respect to the prevalence of family

17 Note that fathers of treated children are by 5.6 percentage points more likely to be unemployed. This goes in line with the priority setting policy of after-school care centers to facilitate attendance to children of families in financial distress, as described in Section 4. 
problems, conflict behavior and the external help parents receive regarding their children's education. The comparison shows that mothers of treated children worry significantly more often about problems concerning housework and household duties, face more stress in general as well as related to their job and their partner - all factors going in line with the higher engagement in paid work, the lower household income and the higher prevalence of single motherhood among mothers of treated children. Yet, there are no significant differences with respect to worries about children's health or school performance. Also regarding the conflict behavior mothers of treated children do not differ significantly from mothers of control children. Finally, families do not differ with respect to the external help they receive from pedagogues or psychologists.

\section{Econometric framework}

This section clarifies what we mean by the effect of after-school center-based care on children's development, introduces the empirical strategy and discusses the respective underlying assumptions.

We define the effect of after-school center-based care on a child's development as the difference between a child's development when the child attends after-school center-based care and the development the same child would reach if she did not attend after-school center-based care. Notice that the counterfactual situation comprises alternative scenarios, but refers most likely to care provided by the mother or any other family member (see Sections 1 and 2 for a discussion). While it is crucial to understand the counterfactual situation, it is beyond the scope of this paper to investigate underlying mechanisms. This paper evaluates the average effect of after-school center-based care, as well as the effect for several subgroups that might experience counterfactual care situations that differ substantially in their quality.

When identifying the effect of after-school center-based care on children's development, we face several empirical challenges. First, selection into afterschool center-based care is a non-random decision. One of the main reasons for sending a child to after-school center-based care is a mother's decision to participate in the labor market. In fact, $80 \%$ of mothers in our data state their employment status as the decisive reason to send their children to center-based care. If a mother's decision to work is correlated with her child caring quality or with further individual or family characteristics that directly influence children's development, the unconditional correlations between after-school center-based care attendance and children's development measures as shown in Table 4, 
Panel A do not reflect a causal effect. The direction of the arising bias depends on the relative quality of the care provided by the mother. If mostly high-skilled mothers decide to work and it is those mothers who provide their children with best care and a stimulating environment, our estimates are likely to be upward biased. Yet, if rather women from disadvantaged backgrounds need to engage in the labor market and this type of women cannot guarantee their children highquality care and a stimulating environment, the raw correlations would underestimate the true beneficial effects of after-school center-based care. In addition, a child's prior performance might influence parents' decision to send the child to after-school center-based care. On the one hand, mothers might opt out of work in case their child does not perform sufficiently well. On the other hand, insufficient school performance or conduct problems might constitute a reason for parents to actually send their child to after-school center-based care. A simple "selection-on-observables" approach can control for all observable characteristics that determine after-school center-based care attendance and children's development simultaneously. However, the estimates of this approach would not give us the true effect if there are unobservable characteristics that impact both the decision to send a child to after-school center-based care attendance and a child's development.

The longitudinal nature of the data used in this study allows for two alternative approaches that can handle at least partially the problems arising due to non-random selection into after-school center-based care based on unobservable characteristics. The first approach is the well-known fixed effect framework (FE). The advantage of the FE method is that it eliminates any timeinvariant unobservable characteristics that might confound with children's development and after-school center-based care attendance. The disadvantage of the FE framework is that it fails to deal with (i) reverse causality and (ii) endogeneity of after-school center-based care attendance with respect to previously acquired skills. Regarding the first issue: Besides maternal labor force participation, a child's development constitutes a decisive reason for sending a child to after-school center-based care. Hence, reverse causality is likely to exist in our setting, i.e. a child's school performance as well as behavior causes her after-school center-based care attendance and not vice versa. Regarding the second issue: According to the human capital production theory (Cunha, Heckman, and Lochner 2006), skill formation follows a dynamic process, i.e. earlier acquired skills boost the formation of later skills. As a result, earlier skills might not only determine after-school center-based care attendance, but also the formation of current skills and thus are likely to be confounding variables. A FE framework exploits the changes in outcome and control variables, but fails to model the impact of the level of the lagged 
outcome measures on the current level of the outcome variable. This dynamic can be captured by the second approach - also called the value-added approach (Todd and Wolpin 2007). This approach regresses children's development measures in the current period on after-school care attendance in the previous period as well as on lagged development measures. This procedure has two main advantages: First, by focusing on after-school care attendance in the previous period it rules out reverse causality. By definition, current development cannot influence previous after-school center-based care attendance. Second, by including the set of lagged development indicators as control variables the model respects the concepts of the human capital production function - children's current development is the outcome of previously acquired skills - and the fact that after-school center-based care attendance is likely to depend on children's prior development. Thus, this approach helps us to tackle not only any bias arising due to selection into after-school care based on prior performance but also any bias arising due to unobserved input factors that enter into a child's development up to the previous period. The latter is due to the lagged outcome measures capturing any inputs into children's development up to the first wave. These inputs can be both observed - such as parents' education or household composition - and unobserved - such as parental attention or affection toward the child - and are likely to depend on the actual or perceived personality of the child, e.g. her innate ability, her behavior, her physical or psychological robustness.

Given the described advantages and disadvantages of the alternative methods based on longitudinal data, we believe that the value-added approach fits better the problems arising when modeling children's development process. The equation to be estimated can thus be expressed as follows:

$$
\begin{aligned}
y_{i c t}^{n}= & \alpha_{0}+\operatorname{afterschool}_{i t-1} \delta+\sum_{n=1}^{N} y_{i t-1}^{n} \theta_{n}+X_{i t-1} \alpha_{1}+X_{c t-1} \alpha_{2} \\
& +\sum_{s=1}^{9} S_{t-1}^{s} \alpha_{3}+\sum_{s=1}^{9} S_{t-1}^{s} * \operatorname{urban}_{c t-1} \alpha_{4}+e_{i c t}
\end{aligned}
$$

In this equation $y_{i c t}^{n}$ represents child $i$ 's $n$th development outcome at time $t$ in county $c$. afterschool ${ }_{i t-1}$ is the treatment variable and indicates whether the child at time $t-1$ attends after-school center-based care or not. $X_{i t-1}$ represents child and family characteristics at time $t-1$, while $X_{c t-1}$ represents regional characteristics (at the county level) at time $t-1$. Regarding child characteristics we control for a child's age, gender, low birth weight, innate disorder, nationality, early care attendance and number of siblings; regarding mother 
characteristics we control for her age, education and single parenthood; regarding family characteristics we consider net household income and regarding county characteristics we consider population density, GDP per capita, net migration, unemployment rate, female employment rate and number of primary school-aged children in each county. Finally, we control for a set of state dummies $S_{t-1}^{s}$ and distinguish in each state between more and less urban counties (by including the set of interaction terms between urban counties and state dummies). Notice, that to circumvent any bias due to endogenous controls (Angrist and Pischke 2008), all individual and regional control variables are also taken from the previous period.

The coefficient $\delta$ measures the impact of after-school center-based care on child development as long as the following assumptions are fulfilled. First of all, there is no immediate impact of after-school center-based care attendance on children's development: children's development in the previous period is assumed to be unaffected by center-based care attendance in the previous period. In other words, the effect of attending after-school care only becomes apparent after a certain time of attendance. This assumption might seem quite demanding, in particular in terms of children's socio-behavioral development (school grades might indeed refer to performance in the last exam or even the grade received in the last school year). Nevertheless, if this assumption does not hold true and there is an immediate impact of after-school center-based care on a child's development, coefficient $\delta$ in eq. [1] provides us with a lower bound for the effect of after-school center-based care attendance as part of the effect is then already captured by the coefficients of the lagged outcome. Second, there shall be no further unobserved variables that determine center-based care attendance in the previous period and children's development in the following period that are not captured by the set of development measures in the previous period and the included control variables. For instance, any change in a child's life that might be foreseen by the parents, but not yet experienced by the child - e.g. future labor force participation of the mother, arising marital instability - might constitute such a determinant of parents' decision to send their child to center-based care and influences their child's later development. This scenario requires, however, perfect foresight as well as capability of parents to hide a future change to the child. ${ }^{18}$

18 In a previous version of this paper, we also employ an instrumental variable strategy using the supply of after-school center-based care at the county of residence as an instrument. Unfortunately, regional variation in after-school center-based care does not constitute a sufficiently strong enough instrument to provide precise estimates. We therefore do not present the results based on the instrumental variable estimations in the paper, but provide them upon request. 
Finally, as discussed above, the impact of child care is likely to vary with the counterfactual care situation, i.e. with the quality of care children would receive when not attending center-based care during the afternoon hours. Unfortunately the quality of care is not or at best imperfectly observable for the econometrician. Yet, to address at least partially existing effect heterogeneity, we stratify our analysis according to several dimensions that are not only major determinants of children's after-school center-based care attendance (see Section 3) but also of the quality of the counterfactual care mode (Davis-Kean 2005; Linver, Brooks-Gunn, and Kohen 2002; Yeung, Linver, and Brooks-Gunn 2002). To be more precise, we distinguish with respect to mothers' education - primary education, secondary education and university education. Typical occupations one can work in when holding a primary education degree is a cashier or a hairdresser, when holding a secondary degree a nurse, a child carer or physiotherapist, and when holding a university degree a school teacher, a physician or an engineer. In addition we distinguish with respect to families' net monthly household income - a monthly net income below 2,250 euros, between 2,250 and 3,250 euros and more than 3,250 euros. ${ }^{19}$

\section{Results}

How does participation in after-school center-based care influence children's development? This section presents the results of the value-added approach shown in eq. [1]. We show estimates for the pooled sample as well as for two alternative stratifications: we stratify with respect to (1) the education of the mother, i.e. primary, secondary or university degree; (2) the household income, i.e. net monthly household income of the child's family below 2,250 euros, between 2,250 and 3,250 euros or above 3,250 euros.

\subsection{Baseline results}

Table 5 reports the results based on the value-added approach regressing school performance and socio-behavioral development on previous after-school

19 The three income groups are not chosen ad hoc, but correspond to the income brackets underlying the question asked to the parents participating in the GCP. 
Table 5: Value-added approach results

\begin{tabular}{|c|c|c|}
\hline & School performance & Socio-behavioral development \\
\hline $\begin{array}{l}\text { Panel A: Pooled Sample } \\
\text { Previous after-school care attendance } \\
N=857 \text { (168 treated, } 689 \text { control) }\end{array}$ & $\begin{array}{c}0.064 \\
(0.076)\end{array}$ & $\begin{array}{c}0.022 \\
(0.075)\end{array}$ \\
\hline Panel B: education of mother & & \\
\hline $\begin{array}{l}\text { Primary education } \\
\text { Previous after-school care attendance } \\
N=175 \text { ( } 27 \text { treated, } 148 \text { control) }\end{array}$ & $\begin{array}{c}0.319 \\
(0.235)\end{array}$ & $\begin{array}{l}0.448^{\star *} \\
(0.226)\end{array}$ \\
\hline $\begin{array}{l}\text { Secondary education } \\
\text { Previous after-school care attendance } \\
N=503 \text { ( } 88 \text { treated, } 415 \text { control) }\end{array}$ & $\begin{array}{c}0.104 \\
(0.101)\end{array}$ & $\begin{array}{c}0.145 \\
(0.099)\end{array}$ \\
\hline $\begin{array}{l}\text { University degree } \\
\text { Previous after-school care attendance } \\
N=156 \text { ( } 47 \text { treated, } 109 \text { control) }\end{array}$ & $\begin{array}{c}-0.227 \\
(0.164)\end{array}$ & $\begin{array}{c}-0.210 \\
(0.183)\end{array}$ \\
\hline Panel C: Income of family & & \\
\hline $\begin{array}{l}\text { Low income } \\
\text { Previous after-school care attendance } \\
N=284 \text { ( } 66 \text { treated, } 218 \text { control) }\end{array}$ & $\begin{array}{c}0.190 \\
(0.125)\end{array}$ & $\begin{array}{l}0.261^{\star \star} \\
(0.121)\end{array}$ \\
\hline $\begin{array}{l}\text { Middle income } \\
\text { Previous after-school care attendance } \\
N=297 \text { ( } 46 \text { treated, } 251 \text { control) }\end{array}$ & $\begin{array}{r}0.168 \\
(0.151)\end{array}$ & $\begin{array}{c}-0.012 \\
(0.155)\end{array}$ \\
\hline $\begin{array}{l}\text { High income } \\
\text { Previous after-school care attendance } \\
N=217 \text { ( } 44 \text { treated, } 173 \text { control) }\end{array}$ & $\begin{array}{c}-0.108 \\
(0.158)\end{array}$ & $\begin{array}{c}-0.154 \\
(0.157)\end{array}$ \\
\hline
\end{tabular}

Notes: This table summarizes the results of the value-added regressions. Panel A shows estimates of the after-school care coefficient using the whole sample of 857 children. The first column shows the estimate for the regression of school performance in the second period on after-school care attendance in the first period, both development measures in the first period, individual and regional characteristics in the first period and a set of state dummies and interactions between each state dummy and a dummy indicating whether the county of residence is urban. Individual characteristics include characteristics of the child (age, gender, low birth weight, innate disorder, nationality and early care attendance), the mother (age, education and single parenthood) and the family (number of siblings and net household income). Regional characteristics refer to population density, GDP per capita, net migration, unemployment, female employment and the number of primary school-aged children in each county. The second column shows the result of a corresponding regression with socio-behavioral development as the dependent variable. Panel B shows the respective regression results stratified by mothers' education. Panel $C$ stratifies with respect to the net monthly household income (categories that are used in the survey: below 2,250 euro, between 2,250 and 3,250 euro and above 3,250 euro). Standard errors are in parentheses. ${ }^{\star} p<0.10,{ }^{\star \star} p<0.05,{ }^{\star \star \star} p<0.01$

Source: Own calculations, based on the GCP. 
center-based care attendance, on all previous development dimensions (school performance and socio-behavioral development), on previous individual and regional characteristics as well as on a set of state dummies and interactions between each state dummy and a dummy indicating whether the county of residence is urban. Column 1 shows the results with respect to children's school performance (grades) being the dependent variable, column 2 shows the results with respect to children's socio-behavioral development being the dependent variable.

Could it be that mainly previously worse performing children are sent to after-school care centers? Or is it the case that mainly children from advantaged backgrounds are sent to after-school center-based care? Under any of these scenarios, the raw differences shown in Table 4 are misleading. The estimates based on the value-added approach are purged - at least in terms of observable characteristics - from any bias due to selection into after-school center-based care. As we can see in Panel A of Table 5, the average child attending centerbased care does not perform significantly worse neither with respect to her school performance nor with respect to her socio-behavioral development. In terms of correlations between children's development and further background characteristics we observe the following (see Table 14 in the Appendix): Girls exhibit generally better school grades (by $0.17 \mathrm{sd}$ ) as well as socio-behavioral development (by $0.24 \mathrm{sd}$ ). As expected, mothers' education is highly correlated with children's cognitive development: in comparison to children whose mother has a secondary school degree, children whose mother only has a primary educational degree perform significantly worse in school (by $0.19 \mathrm{sd}$ ), while children whose mother has a university degree fare better (by $0.10 \mathrm{sd}$ ). Children's school performance is moreover monotonically increasing in household's net income: children whose families receive between 2,250 and 3,250 euros net per month fare significantly better than children in families with an income lower than 1,250 euros net per month (by $0.26 \mathrm{sd}$ ); children whose families receive more than 3,250 euros per month exhibit the best grades (by $0.31 \mathrm{sd}$ higher than the performance of children from the poorest families).

Do the estimated correlations between lagged and current development measures support the predictions of the human capital production theory? Do existing skills boost the development in the same skill dimensions or even in further skill dimensions? In terms of children's cognitive performance we observe the following: Grades are significantly correlated with previous grades (0.52), not, however, with previous socio-behavioral outcomes. Interestingly, previous school performance is significantly related with children's sociobehavioral development $(0.05 \mathrm{sd})$, yet to a much lower extent than the 
inter-temporal correlation between previous socio-behavioral development and current socio-behavioral development $(0.50 \mathrm{sd})$. Thus, the estimated correlations between previous skills and current skills provide some evidence in favor of the predictions of the human capital production theory.

The estimates discussed so far display average effects for the impact of center-based care attendance on children's development. Yet, to which extent do these average effects hide differential effects for subgroups? Does afterschool center-based care constitute for certain children a more beneficial care mode than the counterfactual care provided by their mother? Panel B and Panel $\mathrm{C}$ in Table 5 shed some light on potential effect heterogeneities across the following subgroups: mothers with primary, secondary and university degree (Panel B), as well as low, intermediate and high household income (Panel C). The characteristics underlying these strata did not only prove to be major determinants of children's attendance to after-school care centers (see Section 3) but also represent family backgrounds that are likely to differ in the quality of care the mother or any other family member may be able to offer children.

The estimates in Panel B in Table 5 show that children of the least educated mothers exhibit significant and positive returns to after-school care attendance in terms of their socio-behavioral development $(0.45 \mathrm{sd}$, significant at the $5 \%$ significance level). In contrast, after-school care centers do not seem to constitute a superior care mode for children of mothers with a higher educational degree. A similar gradient in returns to after-school center-based care is observed when stratifying with respect to family income: the higher the family income the lower the gains from after-school center-based care attendance (see Panel $\mathrm{C}$ of Table 5). Children of the poorest families gain the most when attending after-school center-based care: the gains in terms of sociobehavioral development amount to $0.26 \mathrm{sd}$ (significant at the $5 \%$ significance level). Children of wealthier households, however, do not gain from after-school center-based care attendance: none of the coefficients with respect to sociobehavioral development or school performance is significantly different from zero.

The results for these stratifications provide some supportive evidence for the relevance of the quality of the counterfactual care mode. Highly educated mothers and wealthier households seem to be able to provide their children with a more stimulating supervision and program during the afternoon hours and thus, attending after-school care centers seems to be less beneficial for their children. In contrast, less educated or less wealthy mothers seem to lack the capacities or opportunities to provide their children with learning support or 
further stimulating activities, and thus their children indeed seem to be better off when attending after-school care centers.

Before discussing the policy relevance of our results, we would like to point out that our results are robust to controlling for the whole set of county dummies instead of controlling for the set of state dummies, the respective interactions with the dummy indicating urban areas and all regional characteristics of the county of residence (see Table 15 in the Appendix). Also under this specification, the average child does neither display significant gain nor harm from afterschool center-based care. Yet, stratifying with respect to mothers' education and household net income reveals again a socio-economic gradient in the returns to after-school center-based care attendance: children from the lowest socioeconomic background have the most to gain when being placed in afterschool center-based care, while children from the best socio-economic background have the most to lose when being placed in after-school center-based care. $^{20}$

\subsection{Discussion}

The empirical analysis conducted in this study reveals two important findings. The first important finding of our study is that on average after-school centerbased care attendance does neither benefit nor harm children's school performance and socio-behavioral development. This finding stands in stark contrast to the first impression gained from a raw mean comparison between the development of children attending after-school center-based care and children not attending after-school center-based care. Yet, drawing the conclusion that investing money into expanding after-school center-based care is like spending money for nothing would be a premature conclusion. Indeed, the second and possibly more interesting finding of our study is that only some subgroups benefit from after-school center-based care. To be more precise, only children from less advantaged families benefit from attending after-school center-based care, while children from more advantaged families are unaffected by attending after-school center-based care.

20 All together there are 76 counties represented in our sample. As such, the latter specification considers 97 control variables (76 county dummies and 23 control variables already included in the baseline specification). Given the rather small sample size, in particular in some of our strata, we abstain from using the latter specification as our baseline specification. 
Yet, can after-school center-based care help to overcome existing disparities between children from different family backgrounds? In our sample, the socio-economic gap ${ }^{21}$ with respect to children's school performance and sociobehavioral development amounts to $0.3-0.4 \mathrm{sd}$. Based on our results, children from the lowest socio-economic background gain between 0.26 and $0.45 \mathrm{sd}$ in terms of their socio-behavioral development when attending after-school centerbased care. Gains in terms of school performance are also positive and range between 0.19 and $0.32 \mathrm{sd}$, but are not significantly different from zero. In other words, our results indicate that after-school center-based care attendance helps to close the socio-economic gap at least in terms of socio-behavioral development.

Taken together, our results provide crucial insights into a design of further expansions of after-school care: expanding after-school care can contribute positively to the development of children, in particular to the development of children of disadvantaged groups. If the target is to overcome existing disparities between children from different family backgrounds a clear priority setting for accepting children into after-school center-based care is necessary. Such a priority setting should be based on criteria such as mothers' education or household net income, proxies for the opportunities and quality of care families might be able to offer to their children. Yet, if the policy aim is to design after-school care centers that guarantee positive returns for all children, independently of their family background, the quality of after-school care centers should be the main objective of future policy reforms. In particular, the quality of care provided by after-school care centers has to match if not even to exceed the quality of care provided by mothers from the best socio-economic families. Nevertheless, to provide concrete policy recommendations further research and in particular research on the counterfactual care modes is necessary.

\section{Conclusions}

How does attendance to after-school care centers affect children's development? In light of increasing employment rates among women with primary school-aged children this question is highly policy relevant.

21 The socio-economic gap refers to the difference between children from the lowest socioeconomic background (e.g. mothers with primary education only and families with a net income of less than 2,250 euros per month) and the highest socio-economic background (e.g. mothers with university education and families with a net income of more than 3,250 euros per month). 
The present study sheds some light on this question using data from the GCP. We exploit the longitudinal nature of these data and employ a value-added approach to address the problems of reversed causality and endogenous selection into after-school center-based care. Our findings do not point to any significant effects of after-school center-based care attendance on the average child. Subgroup analysis, however, reveals substantial effect heterogeneity. Children from a more disadvantaged family background benefit from attending after-school care centers. In particular, children whose mothers possess only a lower educational degree and children living in a low-income family benefit in terms of their socio-behavioral development. On the contrary, children from a more advantaged family background, in terms of maternal education and higher family income, do not exhibit any significant returns. The results presented in this study provide useful insights into current policies aimed at expanding the supply of after-school care centers. First, the priority setting for acceptance to after-school care centers should be clear: priority should be given to children who if not attending after-school care centers would be exposed to a less stimulating environment. Those are children from the most disadvantaged families (in terms of maternal education and family income). Such a priority setting may actually help leveling the playing field between children from the least and most advantaged families. Second, the quality of care provided in after-school care centers should be at the heart of the discussion about expanding after-school center-based care. Only if the care provided in after-school care centers matches or even exceeds the care offered by the most advantaged families, one can make sure that every child benefits from publicly provided after-school center-based care.

Acknowledgments: We appreciate comments and suggestions by Guido Schwerdt, Andreas Steinmayr, Uwe Sunde, Ludger Woessmann, participants at the EALE meeting at University of Torino in September 2013, the EEA meeting at University of Gothenburg in August 2013, the ESPE meeting at Aarhus University in June 2013, at the "Lech am Arlberg Labor Economics Seminar" in January 2013, at the workshop "Economics on Successful Children: Families and Schools” at Aarhus University in January 2013, at the Brown Bag Seminar at St Gallen University in November 2012 and at the Bertelsmann Conference on Family Policy in Berlin in November 2012. We would also like to thank one anonymous referee for helpful comments. 


\section{Appendix}

Table 6: Length of primary school days in Europe and in the US

\begin{tabular}{|c|c|c|c|}
\hline Country & $\begin{array}{l}\text { Length of the school } \\
\text { day }\end{array}$ & Lunch & Recent developments \\
\hline France & $8.30 a m-4.30 p m$ & Lunch in school & \\
\hline Germany & $\begin{array}{l}7.30 \mathrm{am} \text { or } \\
8.30 \mathrm{am}-12.30 \mathrm{pm} \text { or } \\
1.30 \mathrm{pm}\end{array}$ & $\begin{array}{l}\text { Lunch only if all- } \\
\text { day school }\end{array}$ & $\begin{array}{l}\text { In } 2003,4 \text { billion euro program to foster } \\
\text { all-day opening of schools, i.e. until } \\
4 \mathrm{pm} \text { or } 5 \mathrm{pm} \text { at least } 3 \text { times per week. } \\
\text { Yet, the expansion of all-day schools is } \\
\text { very slow. }\end{array}$ \\
\hline England & $9 a m-4 p m$ & $\begin{array}{l}\text { One hour break at } \\
\text { lunchtime }\end{array}$ & $\begin{array}{l}\text { In } 2002 \text { education act: children can } \\
\text { come earlier ( } 8 \mathrm{am}) \text { or stay longer and } \\
\text { enjoy extra activities }(6 \mathrm{pm})\end{array}$ \\
\hline Spain & $\begin{array}{l}9 \mathrm{am} \text { or } 10 \mathrm{am}-12 \mathrm{am}, \\
\text { then } 2.5 \mathrm{~h} \text { break, then } \\
2 \mathrm{pm} \text { or } 3 \mathrm{pm}-4 \mathrm{pm} \text { or } \\
5 \mathrm{pm}\end{array}$ & $\begin{array}{l}\text { Lunch in school } \\
\text { possible }\end{array}$ & Non-stop day approach: $9 \mathrm{am}-2 \mathrm{pm}$ \\
\hline Italy & $\begin{array}{l}\text { Only in the morning if } \\
24 \mathrm{~h} \text { per week or } \\
\text { morning and afternoon } \\
\text { if more hours per week }\end{array}$ & $\begin{array}{l}\text { Lunch in school if } \\
\text { more than } 24 \mathrm{~h} \\
\text { per week }\end{array}$ & $\begin{array}{l}\text { Since } 2009 / 10: \text { Parents can decide: only } \\
\text { mornings or additional afternoon } \\
\text { classes }\end{array}$ \\
\hline Netherlands & $\begin{array}{l}8.30 \mathrm{am}-3 \mathrm{pm} \text { or } 4 \mathrm{pm} \text {, } \\
\text { only to } 2 \mathrm{pm} \text { if non-stop } \\
\text { day }\end{array}$ & $\begin{array}{l}\text { One hour break at } \\
\text { lunchtime }\end{array}$ & $\begin{array}{l}\text { Primary schools increasingly opt for } \\
\text { non-stop day, then lunch in class }\end{array}$ \\
\hline USA & $8.30 \mathrm{am}-3 \mathrm{pm}$ & $\begin{array}{l}\text { One hour break at } \\
\text { lunchtime }\end{array}$ & \\
\hline
\end{tabular}

Source: Kamette (2011) and Patall, Cooper, and Allen (2010).

Table 7: Supply of after-school care slots across states and time

\begin{tabular}{lrrrrr}
\hline State & $\begin{array}{r}\text { Offer rate } \\
\mathbf{1 9 9 8}\end{array}$ & $\begin{array}{rrrr}\text { Offer rate } \\
\mathbf{2 0 0 2}\end{array}$ & $\begin{array}{r}\text { Offer rate } \\
\mathbf{2 0 0 7}\end{array}$ & $\begin{array}{r}\text { Change 1998- } \\
\mathbf{2 0 0 2} \text { in \% }\end{array}$ & $\begin{array}{r}\text { Change 2002- } \\
\text { 2007 in \% }\end{array}$ \\
\hline Baden-Wurttemberg & 3.2 & 4.8 & 5.4 & 48.2 & 12.9 \\
Bavaria & 5.7 & 7.1 & 10.6 & 24.7 & 48.6 \\
Berlin (C) & - & 59.2 & - & - & - \\
Bremen (C) & - & 18.3 & 18.0 & - & -1.7 \\
Hamburg (C) & 23.0 & 24.9 & 28.0 & 8.2 & 12.5 \\
\hline
\end{tabular}


Table 7: (Continued)

\begin{tabular}{lrrrrr}
\hline State & $\begin{array}{r}\text { Offer rate } \\
\mathbf{1 9 9 8}\end{array}$ & $\begin{array}{r}\text { Offer rate } \\
\mathbf{2 0 0 2}\end{array}$ & $\begin{array}{rrrr}\text { Offer rate } \\
\mathbf{2 0 0 7}\end{array}$ & $\begin{array}{r}\text { Change 1998- } \\
\mathbf{2 0 0 2} \text { in \% }\end{array}$ & $\begin{array}{r}\text { Change 2002- } \\
\text { 2007 in \% }\end{array}$ \\
\hline Hesse & 8.3 & 9.9 & 12.4 & 19.6 & 25.2 \\
Lower Saxony & 3.5 & 4.5 & 5.1 & 29.3 & 14.0 \\
North-Rhine & 4.5 & 5.6 & 4.5 & 24.7 & -20.7 \\
$\quad$ Westphalia & & & & & \\
Rhineland-Palatinate & 3.3 & 4.7 & 5.4 & 42.9 & 12.9 \\
Saarland & 3.5 & 6.5 & 7.6 & 88.6 & 16.8 \\
Schleswig-Holstein & 4.8 & 5.5 & 7.0 & 15.8 & 26.5 \\
West Germany & 4.6 & 6 & 7.2 & 33.6 & 14.7 \\
$\quad$ (without C) & & & & & \\
City States & - & 34.1 & - & - & - \\
\hline
\end{tabular}

Source: Riedel et al. (2005, Tables 20 and 44), and Federal Statistical Office: Kinder- und Jugendhilfestatistik.

Table 8: Sample construction

\begin{tabular}{|c|c|c|}
\hline & Young cohort & Old cohort \\
\hline & $\begin{array}{r}\text { Children born } \\
1996 / 1997\end{array}$ & $\begin{array}{r}\text { Children born } \\
1993 / 1994\end{array}$ \\
\hline Original Sample, first period ${ }^{a}$ & 1,148 & 1,042 \\
\hline Without East Germany, Berlin and Bremen & 939 & 833 \\
\hline Interview in second period ${ }^{\mathrm{b}}$ took place & 545 & 575 \\
\hline Child is not implausibly old or young & 544 & 568 \\
\hline Outcome and treatment data are available in first period & 377 & 520 \\
\hline Outcome and treatment data are available in second period & 363 & 494 \\
\hline Final number of observations & 363 & 494 \\
\hline
\end{tabular}

Notes: This table describes the construction of the final sample we use for our analysis. ${ }^{a}$ i.e.

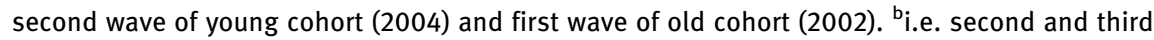
wave of young cohort (2005) and first and second wave of old cohort (2004). 
Table 9: Questions about children's development used in the GCP survey

\section{Emotional skills:}

Is your child sometimes sad?

Is your child sometimes anxious?

Can your child deal with unexpected situations?

\section{Conduct skills:}

Does your child often lose control?

Is your child often angry?

Does your child often start to argue?

Does your child like to annoy others?

\section{Hyperactivity:}

Can your child sit still for longer?

Does your child often fidget?

Does your child often act without thinking?

Is your child concentrated when having started something?

\section{Peer relationships}

Does your child like to meet new children?

How well does your child get along with friends?

How well does your child get along with classmates?

\section{Grades:}

How good is your child in math?

How good is your child in reading?

How good is your child in writing?

Notes: These are the questions on children's development used in the GCP survey. Mothers were asked to report the performance in the school subjects math, reading and writing. Additionally, they had to answer detailed questions on their child's behavior we grouped into the four categories of the SDQ. Mothers could answer the questions based on a scale from 1 to 4 with 1 indicating "agree strongly" and 4 indicating "disagree strongly".

Table 10: Daily activities

\begin{tabular}{|c|c|c|c|c|c|}
\hline & \multirow{2}{*}{$\begin{array}{l}\text { Pooled } \\
\overline{N=857}\end{array}$} & \multirow{2}{*}{$\begin{array}{r}\text { No } \\
\text { afterschool } \\
N=689\end{array}$} & \multirow{2}{*}{$\begin{array}{r}\text { Afterschool } \\
N=168\end{array}$} & \multicolumn{2}{|c|}{$\begin{array}{l}\text { Afterschool vs } \\
\text { no afterschool }\end{array}$} \\
\hline & & & & Difference & Std. error \\
\hline \multicolumn{6}{|l|}{ Panel A. Family life } \\
\hline $\begin{array}{l}\text { Having lunch together with the } \\
\text { family }\end{array}$ & 0.167 & 0.185 & 0.096 & $-0.089^{\star \star \star}$ & $(0.032)$ \\
\hline $\begin{array}{l}\text { Having dinner together with the } \\
\text { family }\end{array}$ & 0.541 & 0.536 & 0.565 & 0.030 & $(0.043)$ \\
\hline \multicolumn{6}{|l|}{ Panel B. Hobbies } \\
\hline Club (Sports, Dancing, etc.) & 0.755 & 0.763 & 0.720 & -0.043 & $(0.037)$ \\
\hline Private Lessons (Music, Sports, etc.) & 0.403 & 0.419 & 0.339 & -0.079 * & $(0.042)$ \\
\hline
\end{tabular}

Notes: The statistics are based on the first period of the GCP survey. All variables are binary variables. Standard errors are in parentheses. ${ }^{\star} p<0.10,{ }^{\star \star} p<0.05,{ }^{\star \star \star} p<0.01$. 
Table 11: Detailed skill development

\begin{tabular}{|c|c|c|c|c|}
\hline & Pooled & No afterschool & Afterschool & Afterschool vs no afterschool \\
\hline & $\mathbf{N}=\mathbf{8 5 7}$ & $N=689$ & $N=168$ & Difference \\
\hline \multicolumn{5}{|c|}{ School performance } \\
\hline Grades & $\begin{array}{l}0.093 \\
(1.003)\end{array}$ & $\begin{array}{c}0.127 \\
(0.998)\end{array}$ & $\begin{array}{c}-0.045 \\
(1.014)\end{array}$ & $\begin{array}{l}-0.172^{\star \star} \\
(0.086)\end{array}$ \\
\hline \multicolumn{5}{|c|}{ Socio-behavioral development } \\
\hline SDQ score & $\begin{array}{c}-0.040 \\
(1.004)\end{array}$ & $\begin{array}{c}0.022 \\
(0.992)\end{array}$ & $\begin{array}{c}-0.292 \\
(1.016)\end{array}$ & $\begin{array}{l}-0.314^{\star \star \star} \\
(0.086)\end{array}$ \\
\hline \multicolumn{5}{|c|}{ Components of the SDQ score: } \\
\hline Emotions & $\begin{array}{r}-0.049 \\
(1.021)\end{array}$ & $\begin{array}{c}-0.013 \\
(0.999)\end{array}$ & $\begin{array}{c}-0.196 \\
(1.100)\end{array}$ & $\begin{array}{l}-0.182^{\star \star} \\
(0.088)\end{array}$ \\
\hline Conduct & $\begin{array}{c}-0.056 \\
(0.989)\end{array}$ & $\begin{array}{c}-0.017 \\
(0.972)\end{array}$ & $\begin{array}{r}-0.216 \\
(1.047)\end{array}$ & $\begin{array}{l}-0.199 \star \star \\
(0.085)\end{array}$ \\
\hline Hyperactivity & $\begin{array}{c}-0.012 \\
(1.021)\end{array}$ & $\begin{array}{c}0.042 \\
(1.017)\end{array}$ & $\begin{array}{r}-0.233 \\
(1.010)\end{array}$ & $\begin{array}{l}-0.275^{\star \star \star} \\
(0.087)\end{array}$ \\
\hline Peer relations & $\begin{array}{l}0.010 \\
(1.021)\end{array}$ & $\begin{array}{c}0.033 \\
(0.999)\end{array}$ & $\begin{array}{c}-0.082 \\
(1.104)\end{array}$ & $\begin{array}{r}-0.115 \\
(0.088)\end{array}$ \\
\hline
\end{tabular}

Notes: The statistics are based on the first period of the GCP survey. Treated children are those children who attended after-school center-based care in the first period. Control children are those children who did not. Standard errors are in parentheses. ${ }^{\star} p<0.10,{ }^{\star \star} p<0.05$, $\star \star \star p<0.01$.

Table 12: Labor market participation of parents

\begin{tabular}{|c|c|c|c|c|c|}
\hline & \multirow[t]{2}{*}{ Pooled } & \multirow[t]{2}{*}{ No afterschool } & \multirow[t]{2}{*}{ Afterschool } & \multicolumn{2}{|c|}{$\begin{array}{l}\text { Afterschool vs } \\
\text { no afterschool }\end{array}$} \\
\hline & & & & Difference & Std. error \\
\hline Mother is working & $\begin{array}{r}0.63 \\
(N=857)\end{array}$ & $\begin{array}{r}0.60 \\
(N=689)\end{array}$ & $\begin{array}{r}0.77 \\
(N=168)\end{array}$ & $0.173^{\star \star \star}$ & $(0.041)$ \\
\hline Partner is working & $\begin{array}{r}0.94 \\
(N=780)\end{array}$ & $\begin{array}{r}0.95 \\
(N=644)\end{array}$ & $\begin{array}{r}0.90 \\
(N=136)\end{array}$ & $-0.056^{\star \star \star}$ & $(0.022)$ \\
\hline Mother has full-time job & $\begin{array}{r}0.15 \\
(N=388)\end{array}$ & $\begin{array}{r}0.13 \\
(N=304)\end{array}$ & $\begin{array}{r}0.23 \\
(N=84)\end{array}$ & $0.101^{\star \star}$ & $(0.043)$ \\
\hline
\end{tabular}

Notes: The statistics are based on the first period of the GCP survey. Treated children are those children who attended after-school center-based care in the first wave. Control children are those children who did not. Standard errors are in parentheses. ${ }^{\star} p<0.10,{ }^{\star \star} p<0.05$, $\star \star \star p<0.01$. 
Table 13: Problems, conflict behavior and external help

\begin{tabular}{|c|c|c|c|c|c|}
\hline & \multirow[t]{2}{*}{ Pooled } & \multirow[t]{2}{*}{$\begin{array}{r}\text { No } \\
\text { afterschool }\end{array}$} & \multirow[t]{2}{*}{ Afterschool } & \multicolumn{2}{|c|}{$\begin{array}{r}\text { Afterschool vs no } \\
\text { afterschool }\end{array}$} \\
\hline & & & & Difference & $\begin{array}{l}\text { Std. } \\
\text { error }\end{array}$ \\
\hline \multicolumn{6}{|l|}{ Panel A. Problems because of... } \\
\hline & $N=857$ & $N=689$ & $s=168$ & & \\
\hline Housework & 0.272 & 0.246 & 0.377 & $0.131^{\star \star \star}$ & $(0.038)$ \\
\hline (Marital) partner & 0.246 & 0.227 & 0.325 & $0.098^{\star \star \star}$ & $(0.037)$ \\
\hline Stress in general & 0.551 & 0.529 & 0.641 & $0.112^{\star \star \star}$ & $(0.043)$ \\
\hline Parents' health & 0.114 & 0.105 & 0.151 & $0.046^{\star}$ & $(0.027)$ \\
\hline Behavior of the child & 0.176 & 0.169 & 0.204 & 0.035 & $(0.033)$ \\
\hline Behavior of adults in family & 0.140 & 0.140 & 0.138 & -0.002 & $(0.030)$ \\
\hline School of child & 0.157 & 0.156 & 0.162 & 0.006 & $(0.031)$ \\
\hline Financial issues & 0.162 & 0.156 & 0.186 & 0.029 & $(0.032)$ \\
\hline Alcohol & 0.026 & 0.022 & 0.042 & 0.020 & $(0.014)$ \\
\hline Child's health & 0.076 & 0.070 & 0.102 & 0.032 & $(0.023)$ \\
\hline Bad relations in family & 0.108 & 0.101 & 0.138 & 0.037 & $(0.027)$ \\
\hline Household duties & 0.269 & 0.254 & 0.329 & $0.075^{\star \star}$ & $(0.038)$ \\
\hline Job-related stress & 0.326 & 0.299 & 0.437 & $0.138^{\star \star \star}$ & $(0.040)$ \\
\hline Lack of time & 0.439 & 0.437 & 0.449 & 0.012 & $(0.043)$ \\
\hline \multicolumn{6}{|l|}{ Panel B. Conflict behavior } \\
\hline $\begin{array}{l}\text { Latest conflict with child was } \\
\text { yesterday }\end{array}$ & $\begin{array}{r}0.443 \\
(N=485)\end{array}$ & $\begin{array}{r}0.438 \\
(N=400)\end{array}$ & $\begin{array}{r}0.471 \\
(N=85)\end{array}$ & 0.033 & $(0.059)$ \\
\hline Shouting at child in conflict & $\begin{array}{r}0.557 \\
(N=846)\end{array}$ & $\begin{array}{r}0.552 \\
(N=683)\end{array}$ & $\begin{array}{r}0.577 \\
(N=163)\end{array}$ & 0.025 & $(0.043)$ \\
\hline Ignoring child after conflict & $\begin{array}{r}0.082 \\
(N=846)\end{array}$ & $\begin{array}{r}0.085 \\
(N=683)\end{array}$ & $\begin{array}{r}0.067 \\
(N=163)\end{array}$ & -0.017 & $(0.024)$ \\
\hline \multicolumn{6}{|l|}{ Panel C. External help } \\
\hline & $N=491$ & $N=402$ & $N=89$ & & \\
\hline $\begin{array}{l}\text { Getting help from child } \\
\text { psychologist or similar }\end{array}$ & 0.283 & 0.269 & 0.348 & 0.080 & $(0.053)$ \\
\hline $\begin{array}{l}\text { Getting help from teacher in school } \\
\text { or similar }\end{array}$ & 0.240 & 0.236 & 0.258 & 0.022 & $(0.050)$ \\
\hline
\end{tabular}

Notes: The statistics are based on the first period of the GCP survey. Treated children are those children who attended after-school center-based care in the first wave. Control children are those children who did not. Standard errors are in parentheses. ${ }^{\star} p<0.10,{ }^{\star \star} p<0.05,{ }^{\star \star \star} p<0.01$. 
Table 14: Value-added results: detailed

\begin{tabular}{|c|c|c|}
\hline & $\begin{array}{r}\text { School } \\
\text { performance }\end{array}$ & $\begin{array}{r}\text { Socio-behavioral } \\
\text { development }\end{array}$ \\
\hline \multirow[t]{2}{*}{ After-school care } & 0.0638 & 0.0220 \\
\hline & $(0.0757)$ & $(0.0751)$ \\
\hline \multirow[t]{2}{*}{ Cognitive skills } & $0.515^{\star \star \star}$ & $0.0540^{\star}$ \\
\hline & $(0.0301)$ & $(0.0298)$ \\
\hline \multirow[t]{2}{*}{ Non-cognitive skills } & 0.00773 & $0.500^{\star \star \star}$ \\
\hline & $(0.0297)$ & $(0.0295)$ \\
\hline \multirow[t]{2}{*}{ Child is 7 years old } & -0.00271 & 0.0657 \\
\hline & $(0.0753)$ & $(0.0748)$ \\
\hline \multirow[t]{2}{*}{ Child is 9 years old } & 0.00527 & 0.0196 \\
\hline & $(0.0843)$ & $(0.0837)$ \\
\hline \multirow[t]{2}{*}{ Child is 10 years old } & 0.145 & $-1.427^{\star}$ \\
\hline & $(0.819)$ & $(0.814)$ \\
\hline \multirow[t]{2}{*}{ Child had low birth weight } & -0.129 & 0.132 \\
\hline & $(0.0893)$ & $(0.0887)$ \\
\hline \multirow[t]{2}{*}{ Child has disorder } & -0.00470 & -0.0777 \\
\hline & $(0.0744)$ & $(0.0739)$ \\
\hline \multirow[t]{2}{*}{ Child is female } & $0.170^{\star \star \star}$ & $0.237^{\star \star \star}$ \\
\hline & $(0.0579)$ & $(0.0575)$ \\
\hline \multirow[t]{2}{*}{ Child's nationality is German } & -0.0659 & 0.0722 \\
\hline & $(0.108)$ & $(0.107)$ \\
\hline \multirow[t]{2}{*}{ Child attended early care } & 0.0886 & -0.0947 \\
\hline & $(0.0776)$ & $(0.0770)$ \\
\hline \multirow[t]{2}{*}{ Mother's education: primary } & $-0.186^{\star \star}$ & -0.0119 \\
\hline & $(0.0760)$ & $(0.0755)$ \\
\hline \multirow[t]{2}{*}{ Mother's education: university } & 0.0991 & 0.122 \\
\hline & $(0.0810)$ & $(0.0804)$ \\
\hline \multirow[t]{2}{*}{ Mother is single } & -0.0938 & -0.121 \\
\hline & $(0.134)$ & $(0.133)$ \\
\hline \multirow[t]{2}{*}{ Age of mother: under 30} & 0.161 & $-0.248^{\star}$ \\
\hline & $(0.129)$ & $(0.128)$ \\
\hline \multirow[t]{2}{*}{ Age of mother: $30-34$} & 0.0589 & $-0.186^{\star \star}$ \\
\hline & $(0.0836)$ & $(0.0830)$ \\
\hline \multirow[t]{2}{*}{ Age of mother: $40-44$} & -0.0178 & 0.0363 \\
\hline & $(0.0691)$ & $(0.0687)$ \\
\hline \multirow[t]{2}{*}{ Age of mother: $45-49$} & 0.00332 & 0.128 \\
\hline & $(0.118)$ & $(0.117)$ \\
\hline \multirow[t]{2}{*}{ Age of mother: 50 plus } & 0.252 & 0.0162 \\
\hline & $(0.339)$ & $(0.337)$ \\
\hline \multirow[t]{2}{*}{ Child has siblings } & -0.0666 & -0.102 \\
\hline & $(0.0871)$ & $(0.0865)$ \\
\hline
\end{tabular}


Table 14: (Continued)

\begin{tabular}{lcr}
\hline & $\begin{array}{c}\text { School } \\
\text { performance }\end{array}$ & $\begin{array}{r}\text { Socio-behavioral } \\
\text { development }\end{array}$ \\
\hline Total net income 1,250-2,250 euros/month & 0.113 & -0.0450 \\
& $(0.142)$ & $(0.141)$ \\
Total net income 2,250-3,250 euros/month & $0.262^{\star}$ & 0.0736 \\
& $(0.144)$ & $(0.143)$ \\
Total net income higher than 3,250 euros/ & $0.314^{\star \star}$ & 0.148 \\
month & & \\
& $(0.154)$ & $(0.152)$ \\
Population density & 0.0000123 & -0.0000112 \\
& $(0.0000570)$ & $(0.0000566)$ \\
Unemployment rate & -0.0474 & -0.0362 \\
& $(0.0642)$ & $(0.0637)$ \\
Female employment rate & 0.0816 & 0.0423 \\
Net migration & $(0.0737)$ & $(0.0732)$ \\
& -0.00813 & 0.0153 \\
GDP p.c. in 1,000 euros & $(0.0106)$ & $(0.0106)$ \\
& 0.00281 & -0.00479 \\
\% of children aged 6-10 & $(0.00407)$ & $(0.00405)$ \\
Constant & 0.106 & -0.183 \\
& $(0.124)$ & $(0.123)$ \\
State dummies & -1.161 & 0.778 \\
State dummies*urban & $(0.740)$ & $(0.735)$ \\
$r^{2}$ & YES & YES \\
\hline
\end{tabular}

Notes: This table summarizes results of the value-added regressions using the whole sample of 857 children. The first column shows the estimate for the regression of school performance in the second period on after-school care attendance in the first period, individual and regional characteristics in the first period, state dummies and state*urban interaction terms, and on both development measures in the first period. The second column shows the result of a corresponding regression with socio-behavioral development as dependent variable. Standard errors are in parentheses. ${ }^{*} p<0.10,{ }^{* \star} p<0.05,{ }^{* \star \star} p<0.01$.

Source: Own calculations, based on the GCP. 
Table 15: Sensitivity analysis: using county dummies

\begin{tabular}{|c|c|c|}
\hline & School performance & Socio-behavioral development \\
\hline Panel A: Pooled sample: $\boldsymbol{N}=857$ & 0.029 & -0.021 \\
\hline $\begin{array}{l}\text { Previous after-school care attendance } \\
\text { (168 treated, } 689 \text { control) }\end{array}$ & $(0.079)$ & $(0.078)$ \\
\hline \multicolumn{3}{|l|}{ Panel B: Education of mother } \\
\hline Primary education: $N=175$ & 0.291 & $0.408^{\star}$ \\
\hline $\begin{array}{l}\text { Previous after-school care attendance } \\
\text { (27 treated, } 148 \text { control) }\end{array}$ & $(0.253)$ & $(0.230)$ \\
\hline Secondary education: $N=503$ & 0.080 & 0.100 \\
\hline $\begin{array}{l}\text { Previous after-school care attendance } \\
\text { (88 treated, } 415 \text { control) }\end{array}$ & $(0.109)$ & $(0.111)$ \\
\hline University degree: $N=156$ & $-0.441^{\star \star}$ & -0.345 \\
\hline $\begin{array}{l}\text { Previous after-school care attendance } \\
\text { (47 treated, } 109 \text { control) }\end{array}$ & $(0.193)$ & $(0.231)$ \\
\hline \multicolumn{3}{|l|}{ Panel C: Income of family } \\
\hline Low income: $N=284$ & 0.127 & 0.220 \\
\hline $\begin{array}{l}\text { Previous after-school care attendance } \\
\text { (66 treated, } 218 \text { control) }\end{array}$ & $(0.142)$ & $(0.133)$ \\
\hline Middle income: $N=297$ & 0.133 & -0.106 \\
\hline $\begin{array}{l}\text { Previous after-school care attendance } \\
\text { (46 treated, } 251 \text { control) }\end{array}$ & $(0.165)$ & $(0.179)$ \\
\hline High income: $N=217$ & -0.165 & -0.095 \\
\hline $\begin{array}{l}\text { Previous after-school care attendance } \\
\text { (44 treated, } 173 \text { control) }\end{array}$ & $(0.181)$ & $(0.189)$ \\
\hline
\end{tabular}

Notes: This table summarizes results of the value-added regressions. Panel A shows estimates of the after-school care coefficient using the whole sample of 857 children. The first column shows the estimate for the regression of school performance in the second period on afterschool care attendance in the first period, both development measures in the first period, individual characteristics in the first period and a set of county dummies. Individual characteristics include characteristics of the child (age, gender, low birth weight, innate disorder, nationality and early care attendance), the mother (age, education and single parenthood) and the family (number of siblings and net household income). The second column shows the result of a corresponding regression with socio-behavioral development as dependent variable. Panel B shows the respective regression results for children with respect to their mothers' education. Panel $C$ stratifies with respect to the net monthly household income (categories that are used in the survey: below 2,250 euros, between 2,250 and 3,250 euros, above 3,250 euros). ${ }^{\star} p<0.10,{ }^{\star \star} p<0.05,{ }^{\star \star *} p<0.01$.

Source: Own calculations, based on the GCP. 


\section{References}

Aizer, A. 2004. "Home Alone: Supervision after School and Child Behavior." Journal of Public Economics 88(9-10):1835-48.

Almond, D., and J. Currie. 2011. "Human Capital Development before Age Five." In Volume 4 of Handbook of Labor Economics, Chapter 15, edited by O. Ashenfelter and D. Card, 1315-486. Amsterdam, The Netherlands: Elsevier.

Angrist, J., and J. -S. Pischke. 2008. Mostly Harmless Econometrics: An Empiricist's Companion. Princeton, New Jersey: Princeton University Press.

Aschenbach, T. M., and C. Edelbrock. 1981. "Behavior Problems and Competencies. Reported by Parents of Normal and Disturbed Children Aged 4 Through 16." Monographs of the Society for Research in Child Development 46(188):1-82.

Baker, M., J. Gruber, and K. Milligan. 2008. "Universal Child Care, Maternal Labor Supply, and Family Well-Being." Journal of Political Economy 116(4):709-45.

Black, S. E., P. J. Devereux, and K. G. Salvanes. 2005. "Why the Apple Doesn't Fall Far: Understanding Intergenerational Transmission of Human Capital." American Economic Review 95(1):437-49.

Blau, D. 1999. "The Effect of Income on Child Development." The Review of Economics and Statistics 81(2):261-76.

Blau, D., and J. Currie. 2006. “Pre-School, Day Care, and After-School Care: Who's Minding the Kids?" In Volume 2 of Handbook of the Economics of Education, Chapter 20, edited by E. Hanushek and F. Welch, 1163-278. Amsterdam, The Netherlands: Elsevier.

Brooks, P., C. Mojica, and R. Land. 1995. "Final Evaluation Report. Longitudinal Study of LA's Best After School Education and Enrichment Program.” Report, Center for the Study of Evaluation. University of California, Los Angeles, CA.

Cascio, E. U. 2009. "Do Investments in Universal Early Education Pay Off? Long-Term Effects of Introducing Kindergartens into Public Schools.” NBER Working Papers 14951, National Bureau of Economic Research, Inc.

Case, A., D. Lubotsky, and C. Paxson. 2002. "Economic Status and Health in Childhood: The Origins of the Gradient.” American Economic Review 92(5):1308-34.

Cunha, F., J. J. Heckman, and L. Lochner. 2006. "Interpreting the Evidence on Life Cycle Skill Formation." In Volume 1 of Handbook of the Economics of Education, Chapter 12, edited by E. Hanushek and F. Welch, 697-812. Amsterdam, The Netherlands: Elsevier.

Currie, J. 2009. "Healthy, Wealthy, and Wise: Socioeconomic Status, Poor Health in Childhood, and Human Capital Development." Journal of Economic Literature 47(1):87-122.

Datta-Gupta, N., and M. Simonsen. 2010. "Non-Cognitive Child Outcomes and Universal High Quality Child Care." Journal of Public Economics 94(1-2):30-43.

Davis-Kean, P. 2005. "The Influence of Parent Education and Family Income on Child Achievement: The Indirect Role of Parental Expectations and the Home Environment. Journal of Family Psychology 19(2):294-304.

Dustmann, C., A. Raute, and U. Schönberg. 2012. "Does Universal Child Care Matter? Evidence from a Large Expansion in Pre-School Education." mimeo.

Eurostat. 2011. Beschaeftigungsquote von Erwachsenen nach Geschlecht, Altersgruppe, hoechstem erreichten Bildungsgrad, Zahl der Kinder und Alter des juengsten Kindes (\%) [lfst_hheredch]. 
Felfe, C., N. Nollenberger, and N. Rodriguez-Planas. 2013. “Can’t Buy Mommy's Love? Universal Childcare and Children's Long-Term Cognitive Development.” CESifo Working Paper Series 4069.

Fitzpatrick, M. D. 2008. "Starting School at Four: The Effect of Universal Pre-Kindergarten on Children's Academic Achievement.” The B.E. Journal of Economic Analysis \& Policy 8(1):46.

Grossman, J., M. Price, V. Fellerath, L. Jucovy, L. Kotloff, R. Raley, and K. Walker. 2002. "Multiple Choices after School: Findings from the Extended-Service Schools Initiative." Report, Public/Private Ventures, Philadelphia.

Havnes, T., and M. Mogstad. 2011. "No Child Left Behind: Subsidized Child Care and Children's Long-Run Outcomes.” American Economic Journal: Economic Policy 3(2):97-129.

Heimer, A., M. Henkel, and D. Donges. 2011. "Vereinbarkeit von Familie und Beruf mit Schulkindern." Report, Federal Ministry of Family, Senior Citizens, Women and Youth, Germany.

Huang, D., B. Gribbons, K. Kim, C. Lee, and E. Baker. 2000. “A Decade of Results: The Impact of LA's Best after School Enrichment Program on Subsequent Student Achievement and Performance." Report, UCLA Center for the Study of Evaluation, Los Angeles, CA.

Huang, D., S. Leon, D. La Torre, and S. Mostafavi. 2008. "Examining the Relationship between LA's Best Program Attendance and Academic Achievement of LA's Best Students." Report, CRESST Report 749.

Kamette, F. 2011. "Organisation of School Time in the European Union." Report, Foundation Robert Schuman, European issues no 212.

Kling, J. R., J. B. Liebman, and L. F. Katz. 2007. "Experimental Analysis of Neighborhood Effects." Econometrica 75(1):83-119.

Linver, M., J. Brooks-Gunn, and D. Kohen. 2002. "Family Processes as Pathways from Income to Young Children's Development." Developmental Psychology 38:719-34.

Patall, E., H. Cooper, and A. B. Allen. 2010. "Extending the School Day or School Year: A Systematic Review of Research (1985-2009)." Review of Educational Research 80(3):401-36.

Riedel, B., T. Gadow, E. van Santen, K. Fuchs, M. Schilling, and H. R. Leu. 2005. "Zahlen-spiegel 2005: Kindertagesbetreuung im Spiegel der Statistik.” Technical report, Deutsches Jugendinstitut e.V. und Dortmunder Arbeitsstelle Kinder- und Jugendhilfestatistik.

Todd, P. E., and K. I. Wolpin. 2007. "The Production of Cognitive Achievement in Children: Home, School, and Racial Test Score Gaps." Journal of Human Capital 1(1):91-136.

U.S. Bureau of Labor Statistics. 2011. Women in the Labor Force: A Databook. Report 1034.

Wahl, K. 2008. "Lachen, Weinen, Ärgern: Die Gefühlswelt Der Kinder "Emotionen, Kompetenzen, Risiken.” Deskription der Daten der ersten Welle des DJI Kinderpanel. Technical report, Deutsches Jugendinstitut e.V.

Windle, M., and R. Lerner. 1986. "Reassessing the Dimensions of Temperamental Individuality across the Life Span. the Revised Dimensions of Temperamant Survey (DOTS-R)." Journal of Adolescent Research 1:213-30.

Yeung, J., M. Linver, and J. Brooks-Gunn. 2002. "How Money Matters for Young Children's Development: Parental Investment and Family Processes." Child Development 73:1861-79. 